\title{
Modified Sequential Deposition Route through Localized-Liquid-Liquid-Diffusion for Improved Perovskite Multi-Crystalline Thin Films with Micrometer-Scaled Grains for Solar Cells
}

\author{
Tao Ling, Xiaoping Zou *, Jin Cheng, Xiao Bai, Haiyan Ren and Dan Chen \\ Research Center for Sensor Technology, Beijing Key Laboratory for Sensor, Ministry of Education Key \\ Laboratory for Modern Measurement and Control Technology, School of Applied Sciences, Beijing Information \\ Science and Technology University, Jianxiangqiao Campus, Beijing 100101, China; 15652869292@163.com (T.L.); \\ nanocheng@163.com (J.C.); baixiao_edu@163.com (X.B.); 18801139192@163.com (H.R.); \\ 13436934850@139.com (D.C.); \\ * Correspondence: xpzou2005@gmail.com; Tel.: +86-136-4105-6404
}

Received: 13 May 2018; Accepted: 6 June 2018; Published: 9 June 2018

\begin{abstract}
High-class perovskite film with beautiful surface morphology (such as large-size grain, low defect density, good continuity and flatness) is normally believed to be a very important factor for high-efficiency perovskite solar cells (PSCs). Here, we report a modified sequential deposition route through localized-liquid-liquid-diffusion (LLLD) for qualified perovskite multi-crystalline thin films with micrometer-scaled grains for solar cells. We adopted a contact-type drop method to drop Methylammonium iodide (MAI) solution and have successfully used high-concentration MAI solution $(73 \mathrm{mg} / \mathrm{mL})$ to transform $\mathrm{PbI}_{2}$ film into high-class perovskite film via our route. A high efficiency of $10.7 \%$ was achieved for the device with spongy carbon film deposited on a separated FTO-substrate as a counter electrode under one sun illumination, which is the highest efficiency (as 2.5 times as previous efficiency) ever recorded in perovskite solar cells with a such spongy carbon/FTO composite counter electrode. The preparation techniques of high-class perovskite thin films under ambient conditions and the cheap spongy carbon/FTO composite counter electrode are beneficial for large-scale applications and commercialization.
\end{abstract}

Keywords: localized-liquid-liquid-diffusion; modified sequential deposition route; perovskite thin film; solar cells

\section{Introduction}

In recent years, perovskite solar cells (PSCs) have been recognized as the most promising alternative to conventional photovoltaic devices due to their high efficiency and simple process [1-3]. High-class perovskite thin film, with beautiful surface morphology (such as large-size grain, low defect density, good continuity, and flatness), is normally believed to be a very important factor for high-efficiency perovskite solar cells [4-8]. M. Grätzel et al. firstly developed the sequential deposition method (so-called two-step method) to prepare $\mathrm{CH}_{3} \mathrm{NH}_{3} \mathrm{PbI}_{3}$ perovskite thin films [9]. Since then, a lot of effort has been paid to developing the two-step method, similar to the two-step spin-coating process [10-12], and $\mathrm{Xu}$ et al. have demonstrated that the two-step spin coating method enables perovskite layer morphology to control and easily fabricate products [13]. Previous researchers prepared perovskite films via the conventional two-step coating method with a necessary step of $\mathrm{PbI}_{2}$ layer annealing [9-13]. In fact, we found the properties of the perovskite thin film are very sensitive to the annealing time of $\mathrm{PbI}_{2}$ layer especially under the dry ambient conditions used in our experiments. 
Xu et al.'s previous study on the effect of humidity on the crystallization of two-step spin-coated perovskites suggested that appropriate moisture can facilitate the reaction between $\mathrm{PbI}_{2}$ and MAX $(\mathrm{X}=\mathrm{I}, \mathrm{Cl})$, whereas the $\mathrm{PbI}_{2}$ film reacts with MAX slowly a under dry inert atmosphere [14]. $\mathrm{H}_{2} \mathrm{O}$ helps MAI to penetrate into the thick $\mathrm{PbI}_{2}$ to form thick film with a pure $\mathrm{MAPbI}_{3}$ phase and produce bigger gains by slowing down the perovskite crystallization rate [15]. However, the dry atmosphere ( $10 \%$ relative humidity) was our experimental condition.

In order to explore the effect of the annealing time of $\mathrm{PbI}_{2}$ thin film on properties of corresponding perovskite thin film, we annealed $\mathrm{PbI}_{2}$ film at $70{ }^{\circ} \mathrm{C}$ for $0 \mathrm{~s}, 10 \mathrm{~s}$, and $20 \mathrm{~s}$, respectively. We found that the $0 \mathrm{~s}$ annealing $\mathrm{PbI}_{2}$ film was more conducive to the formation of high-class perovskite films in our experiment, which means that the sequential deposition route through LLLD is more conducive to the formation of qualified perovskite multi-crystalline films. In addition, we adopted a contact-type drop method to drop MAI solution in order to reduce the damage of MAI solution to $\mathrm{PbI}_{2}$ thin liquid film (illustrated in Figure 1).

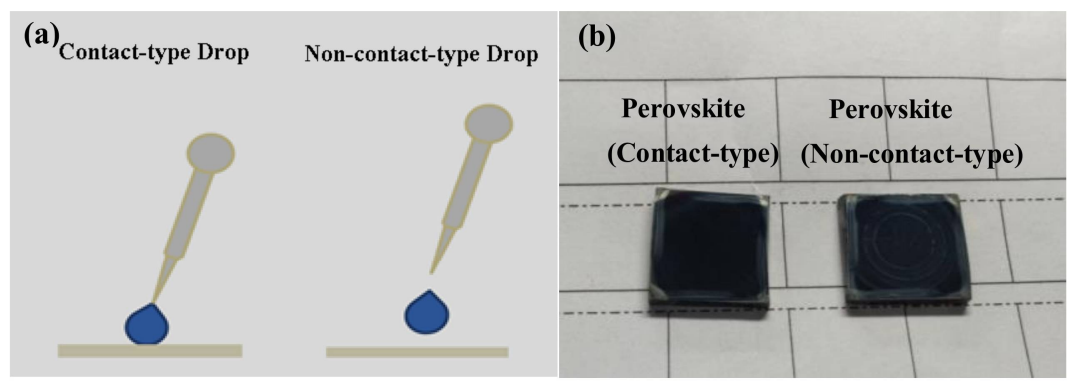

Figure 1. Schematic illustrations for drop method and picture of perovskite films: (a) Schematic illustrations for contact-type method and non-contact-type method to drop MAI solution; (b) Picture of perovskite films dropped by contact-type method and non-contact-type method.

Previously, if MAI concentration is too high $(\geq 70 \mathrm{mg} / \mathrm{mL})$, most of the $\mathrm{PbI}_{2}$ precursor gets dissolved and exists as $\mathrm{PbI}_{4}{ }^{2-}$ in the solution, and only very little can reprecipitate to form $\mathrm{MAPbI}_{3}$ nanostructures [16]. Im et al. found that the size of the $\mathrm{MAPbI}_{3}$ cuboids increases with decreasing $\mathrm{CH}_{3} \mathrm{NH}_{3} \mathrm{I}$ concentration [17]. However, the MAI concentration in our experiment was $73 \mathrm{mg} / \mathrm{mL}$ and the corresponding MAI solution also successfully transformed $\mathrm{PbI}_{2}$ film into high-class perovskite film via LLLD. A high-class perovskite film with micrometer-scaled grain, low defect density, densification, and flatness was obtained by our process.

The tune of the formation process and composition of the light-absorber layer in PSCs has contributed to obtaining certified power conversion efficiencies (PCE) $>20 \%[18,19]$. These PCEs have been obtained while perovskite solar cells were prepared using the single-step method (in combination with solvent engineering) or sequential deposition method or vapor deposition with an important step of device fabrication being the thermal evaporation of metals to form the counter electrode (CE). However, the cost of these metallic CEs is prohibitively high for large-scale applications and commercialization.

Up to now, some researchers have developed carbon CEs to cut the costs of perovskite devices [20-23]. Yang et al. prepared a 2.6\%-efficient perovskite solar cell with candle soot film deposited on a separated substrate as the carbon/FTO composite counter electrode [22]. In our research group, previously, a spongy carbon/FTO composite structure was adopted as a counter electrode and the corresponding cell achieved $4.24 \%$ power conversion efficiency (PCE) [23]. The perovskite solar cell was prepared via a modified sequential deposition route through LLLD under dry ambient conditions and got a $10.7 \%$ PCE in the size of $0.2 \mathrm{~cm}^{2}$, which is the highest efficiency ever recorded in perovskite solar cells with such a spongy carbon/FTO composite counter electrode. 


\section{Materials and Methods}

\subsection{Materials}

Fluorine-doped $\mathrm{SnO}_{2}$ (FTO) substrates were obtained from Dalian HeptaChroma Solar Technology Development Corp (Dalian, China). N,N-dimethylformamide (DMF) and dimethyl sulfoxide (DMSO) were purchased from Sa'en Chemical Technology Corp (Shanghai, China). $\mathrm{PbI}_{2}, 18 \mathrm{NR}-\mathrm{T}$ TiO 2 paste $\left(\mathrm{mp}-\mathrm{TiO}_{2}\right)$, acidic titanium dioxide solution $\left(\mathrm{bl}-\mathrm{TiO}_{2}\right)$, Methylammonium iodide (MAI), and isopropyl alcohol (IPA) were purchased from Shanghai MaterWin New Materials Corp, (Shanghai, China). Spiro-OMeTAD solution was purchased from Xi'an Polymer Light Technology Corp (Xi'an, China).

\subsection{Device Fabrication}

Fluorine-doped $\mathrm{SnO}_{2}$ (FTO) substrates were ultrasonically cleaned with mixed solution (detergent and deionized water), glass water (acetone:deionized water:2-propanol = 1:1:1), and alcohol, respectively. Before using, the FTO was cleaned by Ultraviolet Ozone (UVO) for 90 min. Compact $\mathrm{TiO}_{2}$ layer (bl- $\mathrm{TiO}_{2}$ ) was deposited on FTO substrate by spin-coating an acidic titanium dioxide solution at $2000 \mathrm{rpm}$ for $60 \mathrm{~s}$. Then the substrate was annealed on a hotplate at $100{ }^{\circ} \mathrm{C}$ for $10 \mathrm{~min}$, and sintered in a muffle furnace at $500{ }^{\circ} \mathrm{C}$ for $30 \mathrm{~min}$. Mesoporous $\mathrm{TiO}_{2}$ film $\left(\mathrm{mp}-\mathrm{TiO}_{2}\right)$ was coated on bl- $\mathrm{TiO}_{2}$ thin film by spin coating using a commercial $18 \mathrm{NR}-\mathrm{T} \mathrm{TiO}_{2}$ paste $(4 \%$, solid content) at $2000 \mathrm{rpm}$ for $30 \mathrm{~s}$. Subsequently, the substrate was dried on a hotplate at $100{ }^{\circ} \mathrm{C}$ for $10 \mathrm{~min}$, and then sintered in a muffle furnace at $500{ }^{\circ} \mathrm{C}$ for $60 \mathrm{~min}$. After that, $599.3 \mathrm{mg}$ of $\mathrm{PbI}_{2}$ was dissolved in a component solvent (DMF:DMSO = 9.5:0.5) and then spin-coated onto a $\mathrm{TiO}_{2}\left(\mathrm{bl}-\mathrm{TiO}_{2}\right.$ and $\left.\mathrm{mp}-\mathrm{TiO}_{2}\right)$ layer at $1500 \mathrm{rpm}$ for $30 \mathrm{~s}$, and then annealed on a hotplate at $70{ }^{\circ} \mathrm{C}$ for $0 \mathrm{~s}, 10 \mathrm{~s}$, and $20 \mathrm{~s}$, respectively.

After the $\mathrm{PbI}_{2}$ film had cooled down to room temperature, the MAI solution (73 $\mathrm{mg}$ in $1 \mathrm{~mL}$ IPA) was spin coated onto the $\mathrm{PbI}_{2}$ layer at $1500 \mathrm{rpm}$ for $30 \mathrm{~s}$ (without loading time), and then a thermal annealing of $150{ }^{\circ} \mathrm{C}$ for 15 min under low humidity air condition ( $10 \%$ humidity) was processed. The hole transporting layer was deposited on top of the perovskite layer by $3000 \mathrm{rpm}$ for $30 \mathrm{~s}$ using a commercial 2,2' $, 7,7^{\prime}$-tetrakis( $N, N$-dip-methoxyphenylamine)-9,9'-spirobifluorene (Spiro-OMeTAD) solution. Finally, some cleaned FTO glasses were used as substrates to obtain the soot of a burning candle as spongy carbon CEs. The spongy carbon films on FTO glasses were then pressed on the as-prepared uncompleted devices.

\subsection{Characterization}

An X-ray diffractometer (XRD) (Broker, D8 Focus, Beijing, China) was used to obtain XRD spectra from samples of perovskite films deposited on $\mathrm{mp}-\mathrm{TiO}_{2} / \mathrm{bl}-\mathrm{TiO}_{2} / \mathrm{FTO}$ substrates. The morphologies of these perovskite films were watched by a scanning electron microscope (SEM) (Zeiss SIGMA). The as-prepared devices were measured under full sun illumination (AM 1.5, $\left.100 \mathrm{~mW} / \mathrm{cm}^{2}\right)$.

\section{Results and Discussion}

In order to reduce the possible damage of the MAI solution to $\mathrm{PbI}_{2}$ thin liquid film, we adopted a contact-type drop method to drop MAI solution (illustrated in Figure 1a), and the resulting perovskite films are shown in Figure 1b. In contrast to the non-contact-type drop method, this drop method reduced the damage of the MAI solution to $\mathrm{PbI}_{2}$ thin film according to Figure $1 \mathrm{~b}$.

The perovskite films were prepared by sequential deposition route with $\mathrm{PbI}_{2} 0 \mathrm{~s}, 10 \mathrm{~s}$, and $20 \mathrm{~s}$ annealing, which are named as sample A, sample B, and sample C, respectively. Scanning electron microscopy (SEM) images and image of perovskite layers prepared by two-step spin-coating with different $\mathrm{PbI}_{2}$ annealing times are shown in Figure 2. We found that the surfaces of the perovskite layers gradually became a white color with the increase of $\mathrm{PbI}_{2}$ annealing time, according to the image (Figure $2 \mathrm{a}$ ) of the perovskite layers. From the surface SEM image (Figure $2 \mathrm{~b}-\mathrm{d}$ ), it can be found that sample A showed obvious densification, sample B and C have double layers, and the bottom layer is dense and the top layer is loose $\mathrm{PbI}_{2}$ solution film reacts with MAI solution to form a high-class 
perovskite thin film with beautiful surface morphology (such as large-size grain, low defect density, good continuity, and flatness) via LLLD, whereas, $\mathrm{PbI}_{2}$ solid film reacts with MAI solution to form loose perovskite thin film via localized-solid-liquid-diffusion (LSLD). The bottom layers of sample B and $C$ are observed to contain large-size grain, but the top layer of sample B shows some small square holes and the top layer of sample $C$ shows massive square unordered holes.

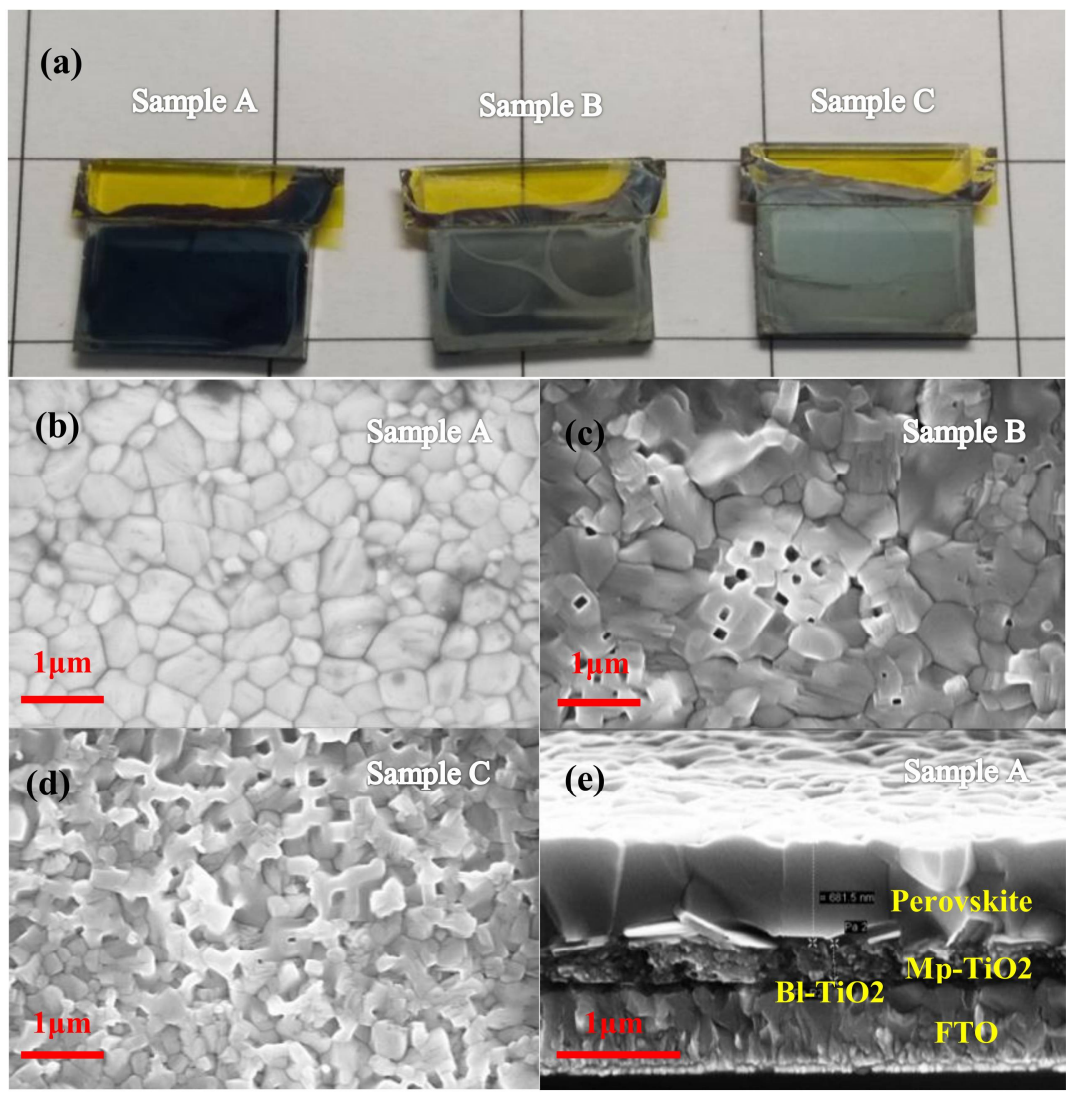

Figure 2. SEM images and picture: (a) Surface picture of perovskite films prepared by sequential deposition route with different $\mathrm{PbI}_{2}$ annealing times $(0 \mathrm{~s}, 10 \mathrm{~s}$ and $20 \mathrm{~s}$; corresponding sample $\mathrm{A}$, sample B and sample C); (b-d) Surface SEM images of sample A, sample B and sample C; (e) Cross-sectional SEM image of sample A.

In the cross-sectional SEM image (Figure 2e) of sample A, we can see the FTO layer, bl- $\mathrm{TiO}_{2}$ layer, $\mathrm{mp}-\mathrm{TiO}_{2}$ layer and perovskite layer clearly from the bottom to the top, and the longitudinal size of perovskite grains equal to the film thickness. This qualified perovskite film (sample A) indicates that the modified sequential deposition route through LLLD is beneficial to the growth of perovskite crystals under dry ambient condition and enhancement of the corresponding photovoltaic performance.

Figure 3 shows XRD pattern of the samples prepared by two-step spin-coating method with different $\mathrm{PbI}_{2}$ annealing times. According to the Figure 3, there are no peaks of $\mathrm{PbI}_{2}$ (corresponding to $\sim 26^{\circ}$ ) and MAI (corresponding to $\sim 19^{\circ}$ ), which means there are no residuals of $\mathrm{PbI}_{2}$ and $\mathrm{MAI}$ in the samples, and the compositions of perovskites in the samples are very pure. As the $\mathrm{PbI}_{2}$ annealing time increased to $10 \mathrm{~s}$, the (004) peak of the tetragonal structure for $\mathrm{CH}_{3} \mathrm{NH}_{3} \mathrm{PbI}_{3}$ emerged, which indicates a phase transition from cubic to tetragonal structure [24]. This result suggest that the perovskite in sample A and bottom layers of sample B and C is cubic structure, and the perovskite in top layers of sample $B$ and $C$ is tetragonal structure. In addition, the intensity ratio ( 2.06) of the highest peak (110) of sample A to its secondary peak (220) is lightly above that of others $(\sim 1.93$ and $\sim 2.01)$. The above points means the crystal structure of sample $\mathrm{A}$ is better than others and 
sequential deposition route through LLLD is more propitious to the formation of qualified perovskite multi-crystalline films, which can enhance the corresponding device efficiency.

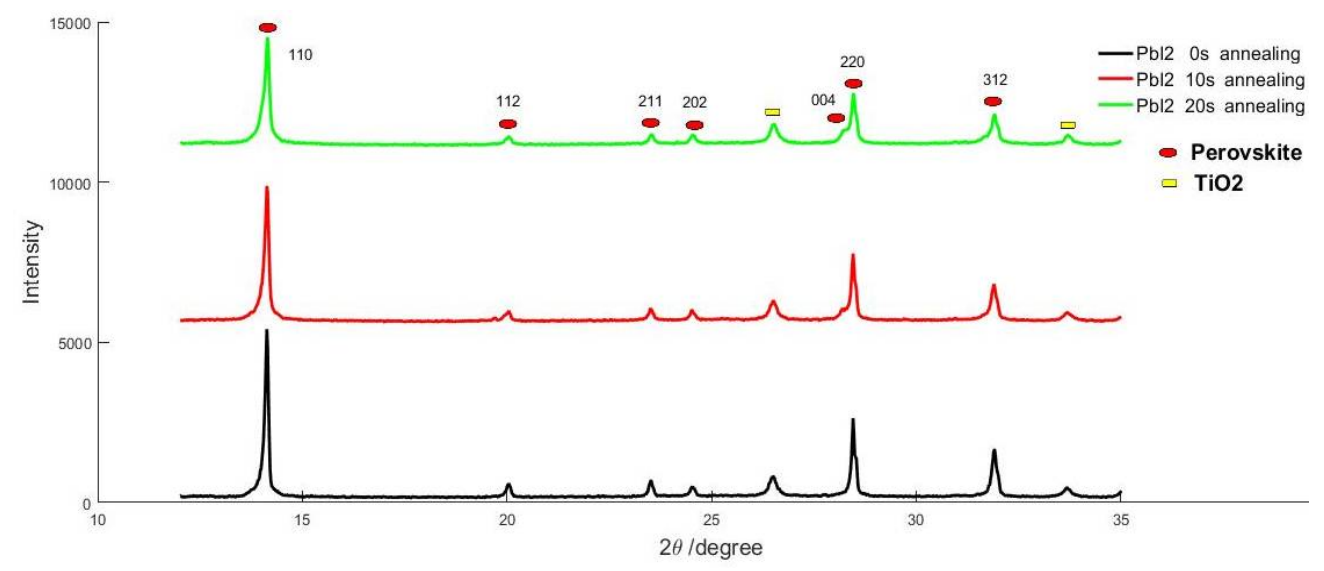

Figure 3. X-ray diffraction (XRD) patterns of perovskite films prepared by sequential deposition route with different $\mathrm{PbI}_{2}$ annealing times.

Schematic illustrations for LLLD and LSLD for qualified perovskite multi-crystalline film are shown in Figure $4 \mathrm{a}$. As $\mathrm{PbI}_{2}$ annealing time increases, its solid part and the ratio of LLLD with MAI solution decreases. The changes in the morphology of the perovskite have finally happened. Due to the $0 \mathrm{~s}$ annealing $\mathrm{PbI}_{2}$ film was the solution state, and MAI could more easily diffuse to the $\mathrm{PbI}_{2}$ thin film interior via LLLD and transform $\mathrm{PbI}_{2}$ film into a high-class cubic structure perovskite film. Moreover, the $\mathrm{PbI}_{2}$ thin film had some of the solvent of DMF, which could facilitate perovskite conversion, improve the film morphology, and reduce crystal defects, and thus enhance charge transfer efficiency [25]. Due to the annealing time being relatively short, there are double layers in the $10 \mathrm{~s}$ annealing $\mathrm{PbI}_{2}$ film and $20 \mathrm{~s}$ annealing $\mathrm{PbI}_{2}$ film. The top layer is solid state, as a result of contacting with air during the spin-coating. MAI is difficult to diffuse to the solid top layer of the $\mathrm{PbI}_{2}$ thin film interior via LSLD and transform into poor perovskite film with a tetragonal structure. The bottom layer is in solution state for having not made contact with air during the spin-coating, which is similar to sample A, and can be transformed into a high-class cubic structure perovskite film. The hydrolysis of perovskite must be reduced because it was prepared in dry air. A combination of the above factors lead to the high-class perovskite films being fabricated by the sequential deposition route through LLLD under dry ambient conditions and the structure of the corresponding devices with the low-cost spongy carbon/FTO composite counter electrode is shown in Figure $4 \mathrm{~b}$.

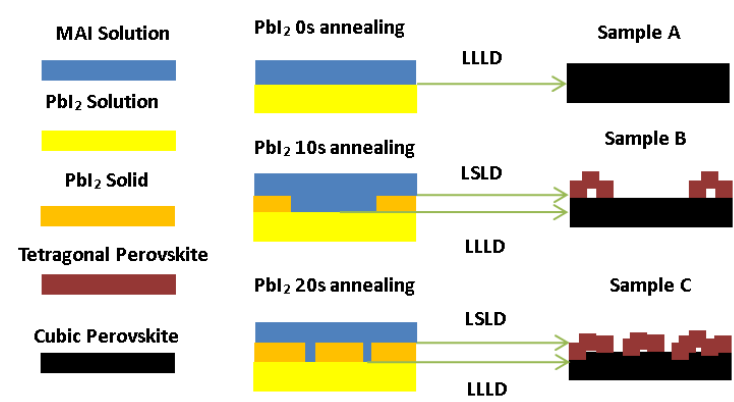

(a)

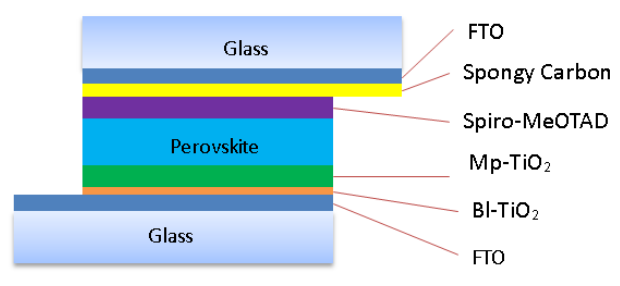

(b)

Figure 4. Schematic illustration for diffusion mechanisms and structure of devices: (a) Schematic illustration for the mechanisms of LLLD and LSLD for perovskite multi-crystalline film; (b) Structure of devices with low-cost spongy carbon/FTO composite counter electrode. 
Figure $5 \mathrm{a}, \mathrm{b}$ show the light current-voltage (J-V) curves from reverse scan (RS) for the devices with a carbon/FTO composite electrode and gold electrode, measured under simulated sunlight with an intensity of $100 \mathrm{~mW} / \mathrm{cm}^{2}$ (AM $1.5 \mathrm{G}$ ). According to the J-V curve, it is found that the device (corresponding to $\mathrm{PbI}_{2} 0 \mathrm{~s}$ annealing) via the modified sequential deposition route through LLLD showed the best performance in major parameters (such as $\mathrm{V}_{\mathrm{oc}}, \mathrm{J}_{\mathrm{sc}}$ and $\mathrm{PCE}$, and their detailed values can be seen in Table 1) and the others showed obvious attenuation in major parameters. To be sure of the efficacy of our new coating processes and the reliability of current density data, we measured the IPCE of the devices with a carbon/FTO composite electrode, and the results are shown in Figure 5c. Generally, the device performance is increased with the decrease of $\mathrm{PbI}_{2}$ annealing times, indicating that the sequential deposition route through LLLD is more conducive to the formation of qualified perovskite multi-crystalline films under dry ambient conditions.

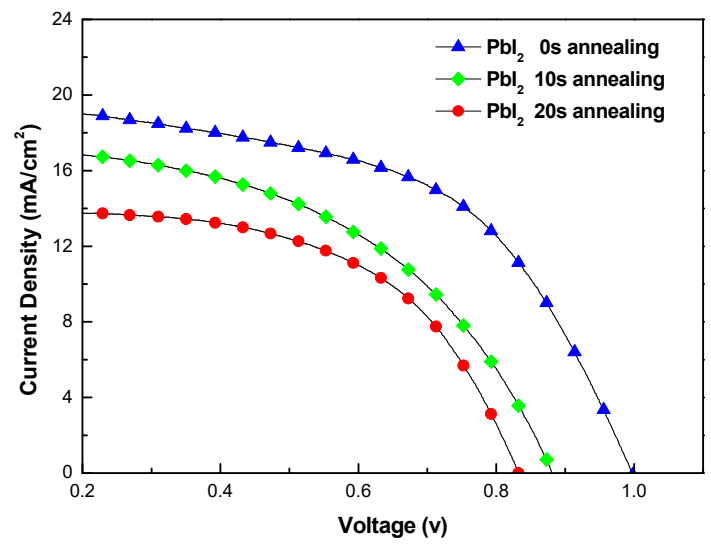

(a)

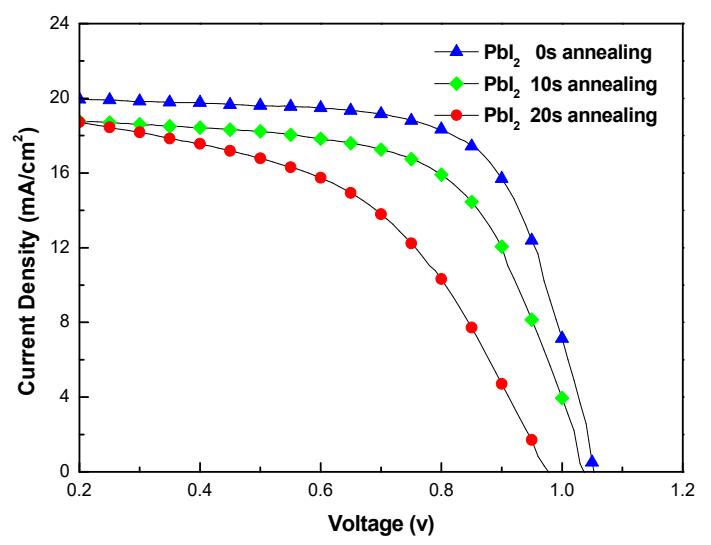

(b)

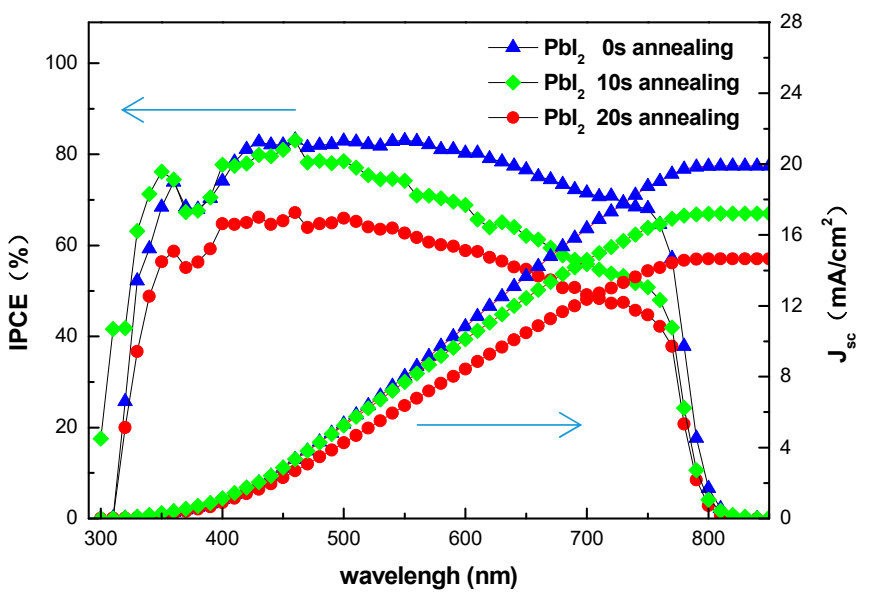

(c)

Figure 5. J-V curves from reverse scan (RS) and monochromatic incident photon-to-electron conversion efficiency (IPCE) of PSCs prepared by sequential deposition route with different $\mathrm{PbI}_{2}$ annealing times: (a) J-V curves for the devices with carbon/FTO composite electrode; (b) J-V curves for the devices with gold electrode; (c) IPCE of devices with carbon/FTO composite electrode.

According to the data of Table 1, it can be found that the photovoltaic performance of contact-type processed PSCs is better than the non-contact-type processed PSCs. This further validates the reduced damage of the MAI solution to the $\mathrm{PbI}_{2}$ thin film when dropping the MAI solution via contact-type method. A high efficiency of $10.7 \%$ was achieved for the device with the carbon/FTO composite electrode. Although this efficiency is not the highest in PSCs, it is the highest efficiency (as 2.5 times 
as previous efficiency) ever recorded in PSCs with such a spongy carbon/FTO composite counter electrode. Furthermore, the preparation techniques of high-class perovskite thin films and the cheap spongy carbon/FTO composite counter electrode, under absolute ambient conditions, are beneficial for large-scale applications and commercialization.

Table 1. Parameters of contact-type or non-contact-type processed PSCs with carbon/FTO composite electrode or gold electrode prepared by sequential deposition route with different $\mathrm{PbI}_{2}$ annealing times under RS.

\begin{tabular}{cccccccc}
\hline $\mathbf{T}^{\mathbf{a}}(\mathbf{s})$ & $\mathbf{D M}^{\mathbf{b}}$ & $\mathbf{E M}^{\mathbf{c}}$ & $\mathbf{J}_{\mathbf{s c}}{ }^{\mathbf{d}}\left(\mathbf{m A} / \mathbf{c m}^{-2}\right)$ & $\mathbf{V}_{\mathbf{o c}}{ }^{\mathbf{e}} \mathbf{( v )}$ & $\mathbf{F F}^{\mathbf{f}}$ & $\mathbf{P C E}^{\mathbf{g}}(\mathbf{\%})$ \\
\hline \multirow{2}{*}{0} & non-contact-type & carbon/FTO & 17.19 & 0.95 & 0.48 & 7.89 \\
\cline { 2 - 7 } & contact-type & carbon/FTO & 19.89 & 1.00 & 0.54 & 10.70 \\
\cline { 2 - 7 } & non-contact-type & gold & 19.69 & 1.02 & 0.66 & 13.29 \\
\cline { 2 - 7 } & contact-type & gold & 20.18 & 1.05 & 0.70 & 14.86 \\
\hline \multirow{2}{*}{10} & contact-type & carbon/FTO & 17.49 & 0.89 & 0.49 & 7.64 \\
\cline { 2 - 7 } & contact-type & gold & 19.11 & 1.04 & 0.64 & 12.73 \\
\hline \multirow{2}{*}{20} & contact-type & carbon/FTO & 14.22 & 0.84 & 0.56 & 6.66 \\
\cline { 2 - 7 } & contact-type & gold & 19.66 & 0.98 & 0.51 & 9.73 \\
\hline
\end{tabular}

${ }^{\mathrm{a}} \mathrm{T}$ : $\mathrm{PbI}_{2}$ annealing times; ${ }^{\mathrm{b}} \mathrm{DM}$ : Drop method of MAI solution; ${ }^{\mathrm{c}}$ EM: Electrode materials; ${ }^{\mathrm{d}} \mathrm{J}_{\mathrm{sc}}$ : Short-circuit photocurrent density; ${ }^{\mathrm{e}} \mathrm{V}_{\mathrm{oc}}$ : Open-circuit voltage; ${ }^{\mathrm{f}}$ FF: Fill factor; ${ }^{\mathrm{g}}$ PCE: Power conversion efficiency.

\section{Conclusions}

A modified sequential deposition route through LLLD was more conducive to the formation of qualified perovskite multi-crystalline thin films with micrometer-scaled grain, low defect density, densification, and flatness under dry ambient condition. The two diffusion mechanisms of LLLD and LSLD were suggested and preliminarily confirmed. A contact-type drop method to drop MAI solution can reduce the damage of MAI solution to $\mathrm{PbI}_{2}$ thin films, and high-concentration MAI solution can also transform $\mathrm{PbI}_{2}$ film into high-class perovskite film via our route. Moreover, a perovskite solar cell was prepared via the modified sequential deposition route through LLLD under absolute ambient conditions and got a $10.7 \%$ PCE in a size of $0.2 \mathrm{~cm}^{2}$, which is the highest efficiency ever recorded in perovskite solar cells with such a spongy carbon/FTO composite counter electrode. Obviously, a great deal of production of high-efficiency perovskite solar cells, with a low-cost spongy carbon/FTO composite counter electrode, under an absolutely ambient atmosphere, is possible.

Author Contributions: T.L. wrote the paper, designed the experiments. J.C. analyzed the data. X.B. and D.C. prepared the samples. H.R. performed all the measurements. X.Z. supervised the project. All authors commented and approved the paper.

Funding: This research was funded by Project of Natural Science Foundation of China (61376057), Project of Natural Science Foundation of Beijing (Z160002), Opened Fund of the State Key Laboratory on Integrated Optoelectronics (IOSKL2016KF19) and Beijing Key Laboratory for Sensors of BISTU (KF20181077203).

Conflicts of Interest: The authors declare no conflict of interest.

\section{References}

1. Park, N.-G. Organometal perovskite light absorbers toward a 20\% efficiency low-cost solid-state mesoscopic solar cell. J. Phys. Chem. Lett. 2013, 4, 2423-2429. [CrossRef]

2. Yin, X.; Guo, Y.J.; Xue, Z.; Xu, P.; He, M.; Liu, B. Performance enhancement of perovskite-sensitized mesoscopic solar cells using $\mathrm{Nb}$-doped $\mathrm{TiO}_{2}$ compact layer. Nano Res. 2015, 8, 1997-2003. [CrossRef]

3. Yang, W.S.; Noh, J.H.; Jeon, J.N.; Kim, Y.C.; Ryu, S.C.; Seo, S.J.; Seok, S.I.I. High-performance photovoltaic perovskite layers fabricated through intramolecular exchange. Science 2015, 348, 1234-1237. [CrossRef] [PubMed] 
4. Stranks, S.D.; Eperon, G.E.; Grancini, G.; Menelaou, C.; Alcocer, M.J.P.; Leijtens, T.; Herz, L.M.; Petrozza, A.; Snaith, H.J. Electron-Hole Diffusion Lengths Exceeding 1 Micrometer in an Organometal Trihalide Perovskite Absorber. Science 2013, 342, 341-344. [CrossRef] [PubMed]

5. Xing, G.; Mathews, N.; Sun, S.; Lim, S.S.; Lam, Y.M.; Gratzel, M.; Mhaisalkar, S.; Sum, T.C. Long-range Balanced Electron- and Hole-Transport Lengths in Organic-Inorganic $\mathrm{CH}_{3} \mathrm{NH}_{3} \mathrm{PbI}_{3}$. Science 2013, 342, 344-347. [CrossRef] [PubMed]

6. Eperon, G.E.; Burlakov, V.M.; Docampo, P.; Goriely, A.; Snaith, H.J. Morphological Control for High Performance, Solution-Processed Planar Heterojunction Perovskite Solar Cells. Adv. Funct. Mater. 2014, 24, 151-157. [CrossRef]

7. Chen, Z.; Li, H.; Tang, Y.; Huang, X.; Ho, D.; Lee, C.-S. Shape-Controlled Synthesis of Organolead Halide Perovskite Nanocrystals and Their Tunable Optical Absorption. Mater. Res. Express 2014, 1, 015034. [CrossRef]

8. Yin, W.J.; Shi, T.; Yan, Y. Unique Properties of Halide Perovskites as Possible Origins of the Superior Solar Cell Performance. Adv. Mater. 2014, 26, 4653-4658. [CrossRef] [PubMed]

9. Burschka, J.; Pellet, N.; Moon, S.-J.; Humphry-Baker, R.; Gao, P.; Nazeeruddin, M.K.; Grätzel, M. Sequential Deposition as a Route to High-Performance Perovskite-Sensitized Solar Cells. Nature 2013, 499, 316-319. [CrossRef] [PubMed]

10. Xiao, Z.; Dong, Q.; Bi, C.; Shao, Y.; Yuan, Y.; Huang, J. Solvent Annealing of Perovskite-Induced Crystal Growth for Photovoltaic-Device Efficiency Enhancement. Adv. Mater. 2014, 26, 6503-6509. [CrossRef] [PubMed]

11. Xiao, Z.; Bi, C.; Shao, Y.; Dong, Q.; Wang, Q.; Yuan, Y.; Wang, C.; Gao, Y.; Huang, J. Efficient, High Yield Perovskite Photovoltaic Devices Grown by Interdiffusion of Solution-Processed Precursor Stacking Layers. Energy Environ. Sci. 2014, 7, 2619-2623. [CrossRef]

12. Chae, J.; Dong, Q.; Huang, J.; Centrone, A. Chloride Incorporation Process in $\mathrm{CH}_{3} \mathrm{NH}_{3} \mathrm{PbI}_{3-\mathrm{x}} \mathrm{Cl}_{\mathrm{x}}$ Perovskites via Nanoscale Bandgap Maps. Nano Lett. 2015, 15, 8114-8121. [CrossRef] [PubMed]

13. Xu, Y.; Zhu, L.; Shi, J.; Lv, S.; Xu, X.; Xiao, J.; Dong, J.; Wu, H.; Luo, Y.; Li, D.; Meng, Q. Efficient Hybrid Mesoscopic Solar Cells with Morphology-Controlled $\mathrm{CH}_{3} \mathrm{NH}_{3} \mathrm{PbI}_{3-\mathrm{x}} \mathrm{Cl}_{\mathrm{x}}$ Derived from Two-Step Spin Coating Method. ACS Appl. Mater. Interfaces 2015, 7, 2242. [CrossRef] [PubMed]

14. Xu, Y.; Zhu, L.; Shi, J.; Xu, X.; Xiao, J.; Dong, J.; Wu, H.; Luo, Y.; Li, D.; Meng, Q. The Effect of Humidity upon the Crystallization Process of Two-Step Spin-Coated Organic-Inorganic Perovskites. ChemPhysChem 2016, 17, 112-118. [CrossRef] [PubMed]

15. Chiang, C.H.; Nazeeruddin, M.K.; Grätzel, M.; Wu, C.G. The synergistic effect of $\mathrm{H}_{2} \mathrm{O}$ and DMF towards stable and 20\% efficiency inverted perovskite solar cells. Energy Environ. Sci. 2017, 10, 808-817. [CrossRef]

16. Fu, Y.; Meng, F.; Rowley, M.B.; Thompson, B.J.; Shearer, M.J.; Ma, D.; Hamers, R.J.; Wright, J.C.; Jin, S. Solution growth of single crystal methylammonium lead halide perovskite nanostructures for optoelectronic and photovoltaic applications. J. Am. Chem. Soc. 2015, 137, 5810-5818. [CrossRef] [PubMed]

17. Im, J.H.; Jang, I.H.; Pellet, N.; Grätzel, M.; Park, N.G. Growth of $\mathrm{CH}_{3} \mathrm{NH}_{3} \mathrm{PbI}_{3}$ cuboids with controlled size for high-efficiency perovskite solar cells. Nat. Nanotechnol. 2014, 9, 927-932. [CrossRef] [PubMed]

18. Kojima, A.; Teshima, K.; Shirai, Y.; Miyasaka, T. Organometal halide perovskites as visible-light sensitizers for photovoltaic cells. J. Am. Chem. Soc. 2009, 131, 6050-6051. [CrossRef] [PubMed]

19. Yang, W.S.; Park, B.-W.; Jung, E.H.; Jeon, N.J.; Kim, Y.C.; Lee, D.U.; Shin, S.S.; Seo, J.; Kim, E.K.; Noh, J.H.; et al. Iodide management in formamidinium-lead-halide-based perovskite layers for efficient solar cells. Science 2017, 356, 1376-1379. [CrossRef] [PubMed]

20. Mei, A.; Li, X.; Liu, L.; Ku, Z.; Liu, T.; Rong, Y.G.; Xu, M.; Hu, M.; Chen, J.; Yang, Y.; et al. A holeconductor-free, fully printable mesoscopic perovskite solar cell with high stability. Science 2014, 345, $295-298$. [CrossRef] [PubMed]

21. Habisreutinger, S.N.; Leijtens, T.; Eperon, G.E.; Stranks, S.D.; Nicholas, R.J.; Snaith, H.J. Carbon nanotube/polymer composites as a highly stable hole collection layer in perovskite solar cells. Nano Lett. 2014, 14, 5561-5568. [CrossRef] [PubMed]

22. Wei, Z.; Yan, K.; Chen, H.; Yi, Y.; Zhang, T.; Long, X.; Li, J.; Zhang, L.; Wang, J.; Yang, S. Cost-efficient clamping solar cells using candle soot for hole extraction from ambipolar perovskites. Energy Environ. Sci. 2014, 7, 3326-3333. [CrossRef] 
23. Zhang, N.; Guo, Y.; Yin, X.; He, M.; Zou, X. Spongy carbon film deposited on a separated substrate as counter electrode for perovskite-based solar cell. Mater. Lett. 2016, 182, 248-252. [CrossRef]

24. Luo, D.; Yu, L.; Wang, H.; Zou, T.; Luo, L.; Liu, Z.; Lu, Z. Cubic structure of the mixed halide perovskite $\mathrm{CH}_{3} \mathrm{NH}_{3} \mathrm{PbI}_{3-\mathrm{x}} \mathrm{Cl}_{\mathrm{x}}$ via thermal annealing. RSC Adv. 2015, 5, 85480-85485. [CrossRef]

25. Wu, J.; Xu, X.; Zhao, Y.; Shi, J.; Xu, Y.; Luo, Y.; Li, D.; Wu, H.; Meng, Q. DMF as an additive in two-step spin coating method for $20 \%$ conversion efficiency perovskite solar cells. ACS Appl. Mater. Interfaces 2017, 9 , 26937-26947. [CrossRef] [PubMed]

2018 by the authors. Licensee MDPI, Basel, Switzerland. This article is an open access article distributed under the terms and conditions of the Creative Commons Attribution (CC BY) license (http://creativecommons.org/licenses/by/4.0/). 